UDC 372.881 .1

\title{
THE IMPORTANCE OF INTEGRATING READING AND WRITING FOR THE EFL TEACHING
}

\author{
O. L. Pysarchyk, N. V. Yamshynska \\ Kyiv, National Technical University of Ukraine \\ "Kyiv Polytechnic Institute" \\ hellen8@ukr.net, tashka78@mail.ru
}

Teaching and learning English are uneasy tasks for both teachers and learners. It causes an urgent demand of high level of English proficiency applying in the study. This article deals with formation and effectiveness of integrating reading and writing skills while learning a foreign language, gives the definition to different skills (writing, speaking, reading, listening), shows stages of writing process, defines the benefits of writing and reading integration. The article views the background of the integrated-skills approach, shows differences between spoken and written language, describes reading as a whole process and gives some examples of activities which can be used at three main stages of this process. The importance of this article is defined by the need of modern schools in professionally savvy specialists, who in excellence possess all the language skills. The value of teaching the primary skills is described and the ways how to maximize their efficiency in the language teaching process by integrating them are discussed. The paper considers teaching strategies for integrating reading and writing skills, describes benefits of integrated-skills approach. This paper presents the research conducted with the purpose to explore effects of integrating reading and writing during the lesson on English language learning. The research findings indicate that the students got better results in post-test of academic reading and writing skills. Modern-day perspectives on skill integration and integrated curriculum designs will also be discussed, together with problems and issues typically associated with integrated teaching.

Key words: integrating skills, learning process, reading, writing, basic skills, teaching strategy, teaching approach.

The article's aim is to investigate and prove the effectiveness of the integratedskills approach applied in teaching English as it is considered to be the most efficient method of language teaching in the modern world. The article provides a brief overview of methods and techniques for integration of writing and reading skills with the aim mentioned above.

Introduction. A Brief History of integrated-skills approach for the EFL teaching. Today, in an age of globalization, the language learning process focuses on the major objective that is meaningful communication and the development of learners' communicative competence through integrated models of all language skills. The ability to read, write, speak and listen makes our graduates productive members of the modern society. Primary language skills have always been essential for achievements in academic and professional sphere. In the $21^{\text {st }}$ century students are facing more complicated problems concerning current standards in reading, writing, speaking and listening. Integration of all four macro-skills contributes to successful communication process.

During a long period of history linguistic scientist considered reading, writing, listening and speaking as separated, perhaps related, language skills. For each of these skills different methods of learning were being developed. They were included in the language learning process as the distinct parts of the lesson. Therefore there weren't any efforts to integrate, for instance reading and writing, for students to achieve higher level of language knowledge and develop their communicative skills. 
The situation has changed from the 1970's when most professionals noticed that that "the teaching of language skills can not be conducted through separate and discrete structural elements" (Corder, 1971; 1978; Kaplan, 1970; Stern, 1992) [1,4,6]. In the real life each person can't use reading, listening, writing skills in isolation. All these skills serve as a bridge that connects a person with a society. The integratedskills approach is relatively new and actual for the recent period of time. For example, Oxford (2001) claimed that integrated language teaching is supposed to be an effective strategy for language learning as a whole [5]. During the last 30 years a lot of linguistic scientists (Widdowson, Savignon, Nunan) have been working on the target of integration of the language skills and considerable advances have been done. New methods and ways how to combine these four language skills have been developing and are offered for teachers to use in their practice.

We can compare ability to speak with the ability to write, saying that speaking is universal while writing is more specific. People learn to write just because of that is required by our modern society, and mostly because someone teaches us to write. The ability to learn and skills have important effects on all social and cultural aspects, because everything we do in our life is learning. For some people such ability may be critical, for others - crucial.

Integrating skills is essential for communicative competence that is the main aim of learning foreign language, for logical structuring of sentences to express ideas and desires both in oral and written form. As we all know, there are two types of language skills: receptive (listening and reading) and productive (speaking and writing). While the development of listening and speaking is simple and quick, the development of reading and writing skills requires persistent and continual study.

Writing. Writing is more difficult skill than reading because students have to balance between the content, organization, vocabulary and spelling, etc. Writing is particularly difficult for learners, because writing is one of the productive skills that demonstrates all acquired skills and experience in foreign language learning. And it so happened that teachers pay most attention to grammar and other practical aspects than on the content and students learn grammar rules not developing ability to express and organize ideas in the written form. This paper focuses on the importance of learning reading in integration with writing for the enhancement of learning process and improvement of all language skills.

The success of language learning is defined only by the students` level of productive skills, and not only academic performance, but also other activities are evaluated through speaking and writing. Writing is one of basic skills that the learner must have to fully complete his/her communicative competence. Therefore, in the case of writing, learner should be more skilled to make communication process most productive. When speaking about such activity as writing, it is worthwhile to name the general keys of this activity. Key concepts of writing include content (information and ideas the learner wants to convey to the readers), style (scientific, general, official or academic), genre (poetry, short story, novel, etc.), vocabulary aspects (it is essential to possess rich enough vocabulary), grammar correctness (formal aspects of language), spelling and other.

Writing is a complex process that requires learner's skills and ability to successfully combine different components of language. While the physical process of writing is completely automatic for learners, the planning and arrangement of ideas is a conscious process that requires considerable time wastes and intellectual contribution. 
Let us define stages of writing process, which can also be defined as visual representation of speech. So, the process of writing consists of the following stages: planning, organization, preview and editing. The initial stage of the written work includes the preparation and planning of goal, main ideas, information gathering. The next step is structuring, that involves creating original composition and logical organization of ideas. At this stage, students select an appropriate structure and vocabulary, including theme to the target auditory. Once all the information is prepared, the aim is specified, the ideas are organized, and the next step is preview, which includes reading the composition, making changes in structure, vocabulary, correcting grammar errors, adding of deleting something. The aim of this stage is to improve the original version of composition. The final stage of the writing process is editing, which includes re-reading and edition composition style. Therefore, the development of writing skills is through the development of all stages. The preparation of writing can be considered using the following scheme:

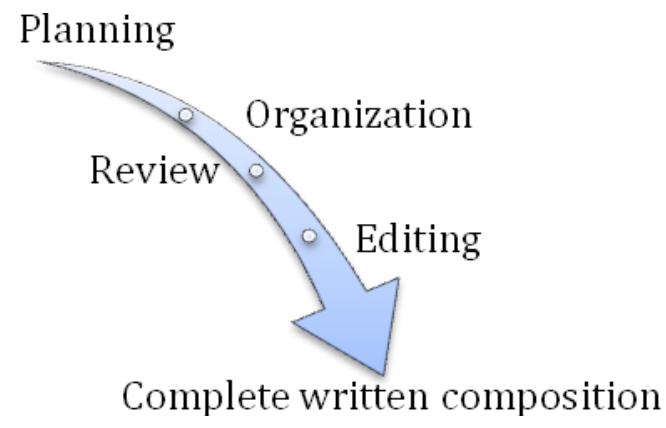

Fig. 1 Stages of the writing process

Let us consider the differences between spoken and written language, paying attention to the following characteristics of language and the benefits of writing: stability, compactness, organization, speed of presenting, total volume and importance. One of the main advantages of writing over speaking is stability. In writing presentation of composition is more fixed and stable, so the reader can read it at any convenient time and pace; whereas oral presentation is in real time, so the listener has to follow the speed of the speaker, and the speaker can interfere at any moment of presentation. The written text in more detailed, while speaking one covers only the main points of theme without any specification. Another advantage is that the written presentation is more carefully formed and organized, grammatically correct, because the writer has the ability and time to edit and improve a written text, while an oral presentation is often improvised. Also preparing for writing composition students have the ability to think over the style of a composition and work it properly, while in an oral presentation it is rather difficult and almost impossible.

Reading. Reading is one of the primary skills and learning to read is an important educational goal. Reading opens a lot of opportunities to foreign language learners. The ability to read allows learners to study new words and phrases, gain new knowledge and experience. The ability to read enables readers to enjoy literature, satisfying their cultural and esthetic needs, can satisfy cognitive needs, psychological primary needs of social individual to know, understand and study.

Most people easily learn to read in their native language, but in a foreign language reading makes a challenge and can cause some difficulties. To eliminate these problems and make reading successful, foreign language teachers must always search and learn for new ways and approaches to make learning process easier and 
most productive for students. Teachers must take into account individual learners' differences including their age, language proficiency level, personal needs and interests, personality traits and individual cognitive abilities and preferences.

Reading is a complicated process, which comprises the following elements: learners`associations of graphical and phonetic language systems, learners` ability to understand the text as a complete and whole, learners` ability to define the main ideas of the target text. The whole process of reading traditionally involves three main stages: pre-, while-, and after-reading activity. Each of these three stages can include different activities and learning tasks. At the pre-reading stage teacher can encourage students to a number of activities with the purpose to raise their motivation to learning, activate vocabulary and warm up the interest of the class before the reading process. Following may include: do scaffolding (helps students to understand a theme of reading), make predictions of the content, establish an aim and objectives to follow while reading, discuss students` background and experiences in the topic, get familiar with unknown words (make predictions, play vocabulary games), etc. The next stage is while-reading activity can constitute from the further actions: to track following objectives previously stated, order main ideas of the text in logical sequence, make questions to the text and find answers to them, keep notes and records, etc.

After reading activities are used to help ESL students to think about and respond to texts they have read. They support students to consider what they have read and are used to help students organize and record information which they might use for other language and literacy related activities such as presentations or writing texts. How this helps ESL students in particular. After-reading activities help students to locate and record relevant information; support students to make connections with what they know and between texts; provide a framework for summarizing key ideas within a text; support students to make inferences and generalizations; help students to substantiate or reconsider their own ideas. Common post reading activities are: creating stories or end of stories, producing posters, reconstructing texts, and questioning the text or views of the writer.

Integrating reading and writing. Integrating skills in EFL learning improves and enhances all basic skills and sub-skills in common. Most students forget about the importance of writing, because it allows better understanding and assimilation of knowledge. It is worth to note that integrating skills contributes to the mastery of foreign language during the whole study, develops an ability to express ideas freely. Some students are quite capable of studying foreign language, only reading and listening, but for the rest it is more complicated and long process, that requires a lot of time and attention. But for all of them the most complicated is to write, but absolutely important, because writing is as important as speaking, listening and reading. Students should be able to compose words into phrases, phrases into sentences and sentences into a complete and meaningful text, write e-mails and letters, etc. They should know the basic rules of writing as well as they should know how to pronounce words properly while speaking.

Let us consider some teaching strategies for integrating different skills for effective EFL studying. One of the activities we can consider is using a reading log making notes and records while reading. While keeping records on reading teacher can assign the following tasks: to make questions to the text and to answer them after reading, to outline main ideas of the text, to make pre-reading predictions before starting reading the text and many other tasks, that are not limited by the teachers`imagination. 
Such activity allows integrating reading and writing, increases students motivation, enhances writing through improving reading. In addition to the basic skills of reading and writing students can activate speaking while discussing the text they have read and sharing ideas, trying to find answers to questions appeared while reading.

Another teaching strategy to integrate language skills is questionnaire. Questionnaire is a research strategy that involves group work, reading and writing, enhances creative and critical skills and also social skills as they have to work in groups with other students. In their article C. Kagnarith, C. Theara and A.Klein define the following stages of questionnaire: forming groups, selecting interesting for students topic, choosing format through brainstorming, writing plan, proofreading, testing and revising final plan before submitting results [3]. So, questionnaire is an excellent way to integrate all basic skills and also activate vocabulary, grammar, pronunciation and other sub-skills. For instance, our students were divided into 3 groups and proposed to make up their own questionnaires on topics like " Travelling". "Evolution", "Social networking". When the questionnaires had been ready, students exchanged by them and gave answers on the questions from the questionnaires of each group.

One of the activities for integrating skills we tried with our students, and here is to describe this experience using peer composition and review. Peer composition that is a kind of activity that involves student's assistance while writing and giving feedback to improve composition. At the first stage the teacher defines the evaluation criteria of writing and gives assignment instructions, then divides students into pairs. Students start writing their compositions with making outline of their written work. During this process students in pairs review compositions of their partners, making notes, providing corrections and giving new ideas. Students help each other correct mistakes, improve organization of ideas and restructure sentences. After students finish their writing work they proofread and make final corrections. The final step is to reread the completed work and grade it according to the teacher-developed evaluation criteria. Then the teacher asks one of the students to volunteer and read his/her written work in front of the class. The role of the teacher in this process is to give instructions and guidelines, observe students ' cooperation and check students' grades. Using peer composition as we can see, focuses mostly on writing but also activates reading while students read their partners' works and speaking while discussion of the writing process; and listening. This activity also increases students' motivation to study a foreign language; includes alternative assessment, when it is done by students themselves; involves pair work that develops social skills and involves content-based study.

The other approach which can be applied for integrating reading and writing activities is doing contrast essays, in which writer concentrates on the organization of ideas, their similarities and differences in the contrast. This activity comprises further elements: comparison of ideas, defining similarities and differences of these ideas and other.

For organizing such teaching strategy the following methods can be usefully utilized: brainstorming (students must compare similar and different aspects of both topics), block method (in which each paragraph addresses one topic only from your pair of topics and includes the shared aspects you have chosen to compare to topic number two) and point-by-point method (each paragraph contains details on one aspect of both topics organized in the same order). 
To explore the effects of integrating writing and reading skills to maximize the effectiveness of EFL learning the following study was conducted. For this research two groups of students (experimental and regular) were taken to analyze their reading and writing skills in pre-test and post-test programs. The participants were university students with intermediate language proficiency level, studying EST. Students of the regular group were continuing their studying process without any changes according to the curricula. On the lessons of the experimental group all mentioned above teaching approaches for integrating writing and reading skills were utilized. Both groups completed 2 kinds of testing (pre-test - before the experiment started at the beginning of the semester, post-test - on the last week of the experiment at the end of the semester). The experiment lasted 1 semester and the results are presented in the table below.

Table 1. The results of the experiment on the effectiveness of writing and reading skills integration

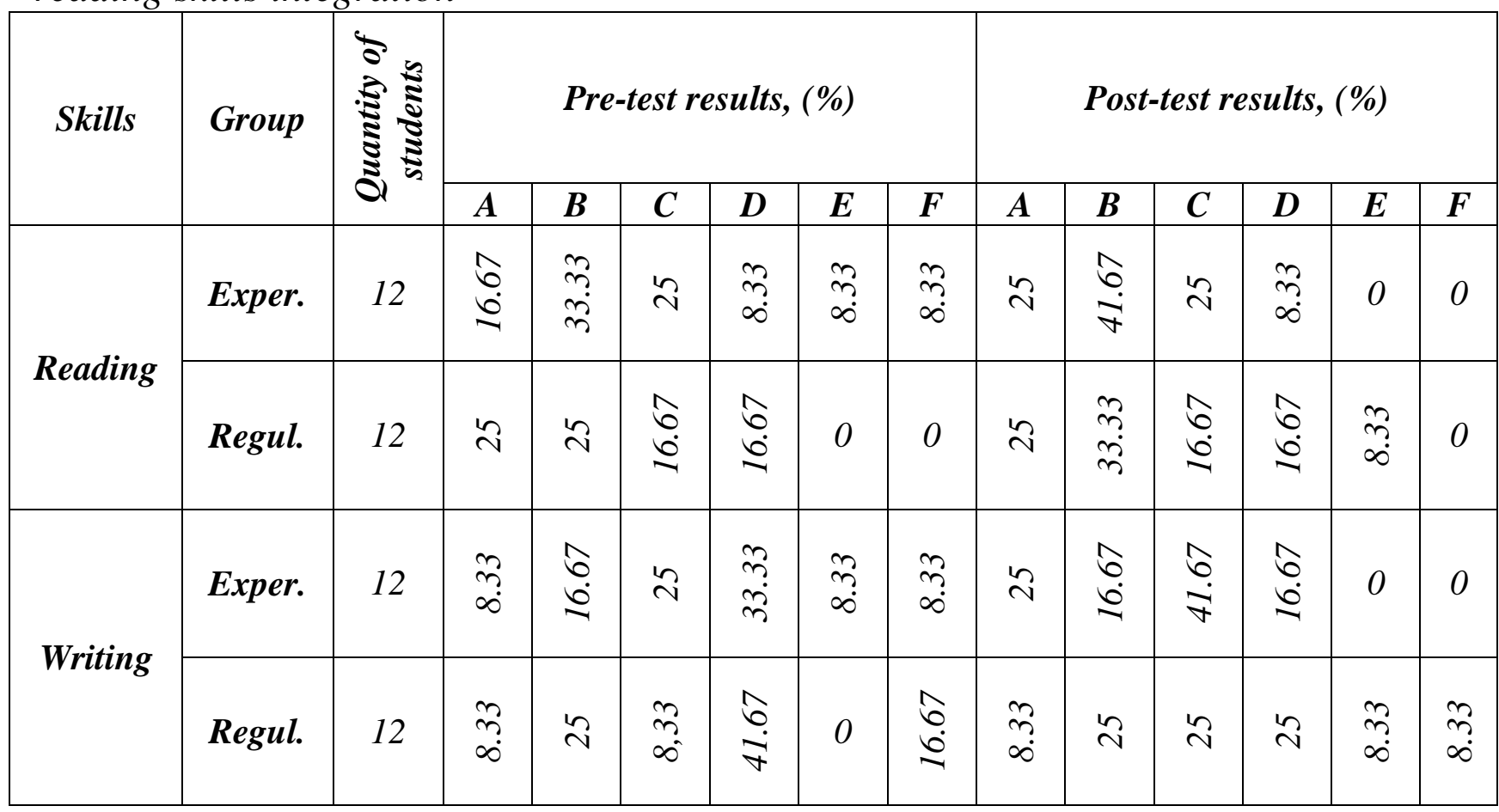

The results in the table show the increase in the language proficiency level as for writing and reading skills in the experimental group comparing with the results of the regular group. The results of reading pre- and post- tests show that the percent of students in the experimental group having A, B, C grades increased from $75 \%$ to $91.67 \%$ (by 16,67\%) while in the regular group this percent of students having A,B,C grades increased only by $8,33 \%$. The similar situation can be observed in the results of writing pre- and post- tests. There is a significant difference between the experimental and regular groups in favor of the experimental class students, their performance raised from $50 \%$ to $83.34 \%$ in comparison with those of the control group's $16.66 \%$. This study emphasizes the importance of combining writing and reading skills in the studying process for students to achieve more benefits in academic proficiency.

Summary. Integrated-skills approach in teaching and learning English as foreign language has a number of benefits. Learning primary receptive and productive skills in integration reinforces each other and maximizes effectiveness of studying language. Integrated-skills approach enables the use of real language in 
task-based approach, establishes social interactions as some of activities described in the article use cooperative learning, group and pair work, contributes to the greater language retention. Another advantage is that integrating skills make possible to develop language skills for students to show their communication competence relying on a written or an oral text, ensure success in academic or professional communication, or everyday interaction.

\section{REFERENCES}

1. $\quad$ Corder, S. P. (1978). Language-learner language. In J. C. Richards (Ed.), Understanding second and foreign language learning (pp. 71-92). Rowley, MA: Newbury House.

2. Kagnarith, C., Theara. C., and Klein, A. (2007). A Questionnaire Project: Integrating the four macro skills with critical thinking. English Teaching Forum 43(1), 2-9. Retrived from: http://americanenglish.state.gov/files/ae/resource_files/0745-1-b.pdf

3. Kaplan, R. (1970). The mind system: A grammar-rule language. Santa Monica, California: The RAND Corporation.

4. Oxford, R. (2001). Integrated skills in the ESL/EFL classroom. ERIC Digest. Retrived from: http://www/cal.org/ericcll/0105oxford.html

5. Stern, H. H. (1992). Issues and Options in Language Teaching. Oxford: Oxford University Press.

О. Л. Писарчик, Н. В. Ямшинська. Важливість інтеграції навичок письма та читання для ефективного викладання англійської мови як іноземної.

Ця стаття присвячена формуванню та ефективності інтеграції мовних навичок, дає визначення різних навичок (письмо, говоріння, читання, аудіювання), розкриває етапи процесу письма, визначає переваги інтеграції письма і читання. Стаття розглядає історію підходу інтеграції навичок та відмінності між усною та письмовою мовою, описує процес читання та завдання на трьох основних етапах процесу читання. Важливість цієї роботи визначається потребою сучасної школи в професійно підготовлених фахівцях, які в достатній мірі володіють всіма мовними навичками. Метою даної роботи є визначення важливості навчання первинних навичок для максимізації іхньої ефективності в процесі викладання іноземних мов шляхом їх інтеграції, розглянути педагогічні стратегії для інтеграції читання та письма та переваги підходу інтергації навичок.

Ключові слова: інтеграція навичок, процес навчання, читання, письмо, базові навички, педагогічна стратегія, підхід до навчання.

\section{Е. Л. Писарчик, Н. В. Ямшинская. Важность интеграции навыков письма и чтения для эффективного преподавания английского языка как иностранного. \\ Эта статья посвящена формированию и эффективности интеграции языковых} навыков, дает определения различных навыков (письмо, говорение, чтение, аудирование), раскрывает этапы процесса письма, определяет преимущества интеграции письма и чтения. Статья рассматривает историю подхода интеграции навыков и различия между устным ы письменным языком, описывает процесс чтения, упражнения на всех этапах чтения. Важность этой работы определяется необходимостью современной школы в профессионально подготовленных специалистах, которые в достаточной мере обладают всеми языковыми навыками. Целью данной работы является определение важности обучения первичных навыков для максимизации их эффективности в процессе преподавания иностранных языков путем их интеграции, рассматривает педагогические стратегии для интеграции чтения и письма и преимущества подхода интеграции навыков.

Ключевые слова: интеграция навыков, процесс обучения, чтение, письмо, базовые навыки, педагогическая стратегия, подход к обучению. 